\title{
Umiejętności studentów kierunku Logistyka wg modelu $T$ (w świetle wyników przeprowadzonego badania)
}

\author{
Agnieszka Bukowska-Piestrzyńska
}

Katedra Logistyki, Wydział Ekonomiczno-Socjologiczny, Uniwersytet Łódzki

\begin{abstract}
Przedsiębiorstwa, chcąc osiągnąć sukces rynkowy, muszą współpracować z innymi uczestnikami rynku (tak z dostawcami, jak i z odbiorcami). Zarządzanie współczesnym przedsiębiorstwem wymaga myślenia o konkurencyjności w ramach całego łańcucha logistycznego (a nie tylko o konkurencyjności danego podmiotu). Artykuł ma charakter teoretyczno-empiryczny. W części teoretycznej odniesiono się do potencjału konkurencyjności logistyki - wskazano kompetencje logistyczne przedsiębiorstw oraz umiejętności logistyczne pracowników wg modelu $T$, a w części empirycznej - przedstawiono wyniki badania własnego, dotyczącego samooceny umiejętności studentów II roku studiów drugiego stopnia na kierunku Logistyka również wg modelu $T$.
\end{abstract}

Słowa kluczowe: kompetencje logistyczne, umiejętności logistyka (menedżerskie, interpersonalne, rozwiązywania problemów, funkcjonalne), studenci logistyki, badanie własne

\section{W prowadzenie}

Orientacja przedsiębiorstwa na klienta przejawia się m.in. respektowaniem zindywidualizowanych oczekiwań klientów (co przekłada się np. na konieczność zapewnienia kompleksowej oferty), szybkim dostarczaniem oferty, utrzymywaniem odpowiednio niskich kosztów, zapewnieniem relatywnie wysokiej jakości. W celu jej praktycznej realizacji podmiot rynkowy musi ściśle współpracować $z$ innymi uczestnikami rynku (tak z dostawcami, jak i z odbiorcami). Tym samym zarządzanie współczesnym przedsiębiorstwem wymaga myślenia o konkurencyjności nie tylko danego podmiotu, lecz także podmiotów z nim ściśle współpracujących. 
Mówiąc o konkurencyjności, można ją potraktować jako sumę czterech podsystemów (Stankiewicz, 2005):

1) pozycji konkurencyjnej ${ }^{1}$,

2) instrumentów konkurowania ${ }^{2}$,

3) potencjału konkurencyjności ${ }^{3}$,

4) przewagi konkurencyjnej, będącej zdolnością do wykorzystywania potencjału konkurencyjnego (by oferować klientowi ofertę o większej wartości dodanej niż konkurencja).

Konkurencyjność przedsiębiorstwa/współpracujących ze sobą przedsiębiorstw może być budowana na fundamentach logistyki, która ze służebnej wobec produkcji roli w połowie ubiegłego wieku urasta dziś do rangi jednego z podstawowych narzędzi zarządczych nie tylko w podmiotach typu profit, lecz także w podmiotach działających w sferze non profit (np. szpitalach). „Myślenie i działanie logistyczne”, jako strategiczna orientacja podmiotu rynkowego, staje się determinantą potencjału konkurencyjnego. A zarządzanie ukierunkowane na doskonalenie procesów oraz odkrywanie nowych logistycznych możliwości i zdolności (mających na celu wzrost efektywności i konkurencyjności podmiotów) (Blaik, 2017) staje się wyzwaniem dla współczesnych menedżerów. Z tego względu kompetencje osób za nie odpowiedzialnych mają znaczny wpływ na efektywność działania podmiotów rynkowych (nie tylko z branży TSL, lecz także z innych branż). Pracownicy „logistyki" zajmują się różnymi jej aspektami - od analityków, logistyków zapotrzebowania materiałowego i menedżerów zakupów, pracowników i kierowników magazynu, koordynatorów poziomu zapasów u sprzedawcy, spedytorów (krajowych i międzynarodowych), po dyspozytorów i specjalistów ds. transportu, dlatego oczekuje się od nich różnych kwalifikacji (i różnego ich poziomu). Zróżnicowanie realizowanych zadań i funkcji pełnionych w podmiotach rynkowych sprawia, że od obecnych i potencjalnych pracowników wymaga się często interdyscyplinarnej wiedzy i wielorakich umiejętności. Pewną uniformizację umiejętności logistycznych przedstawia T-shaped model (Mangan, Christopher, 2005), który wskazuje na ogólne umiejętności z zakresu zarządzania, umiejętności rozwiązywania

1 Definiowanej jako osiągnięty przez przedsiębiorstwo wynik konkurowania w danym sektorze, rozpatrywany w porównaniu z wynikami osiąganymi przez bezpośrednich konkurentów (Simmonds, 1986).

2 Definiowanych jako środki - świadomie planowane i wykorzystywane przez przedsiębiorstwo dla pozyskania nabywców dla posiadanej i/lub planowanej oferty rynkowej.

3 Stanowi on ogół zasobów materialnych i niematerialnych niezbędnych do tego, by przedsiębiorstwo mogło funkcjonować na konkurencyjnym rynku (Stankiewicz, 1999). Może go stanowić logistyka - definiowana regułą $7 R$ (right product, right quantity, right condition, right place, right time, right customer, right price), gdyż charakter jej elementów oraz powiązań pomiędzy nimi decyduje o możliwości budowania przewagi konkurencyjnej oraz o konfigurowaniu możliwych do wykorzystania instrumentów konkurowania. 
problemów i kierowania ludźmi oraz specyficzne (specjalistyczne) umiejętności logistyczne jako te, które powinny charakteryzować logistyka.

W niniejszym artykule w części teoretycznej odniesiono się do potencjału konkurencyjności logistyki - wskazano kompetencje logistyczne przedsiębiorstw oraz umiejętności logistyczne pracowników wg modelu $T$, w części empirycznej zaś przedstawiono wyniki badania własnego (przeprowadzonego wśród studentów kierunku Logistyka na Wydziale Ekonomiczno-Socjologicznym Uniwersytetu Łódzkiego) oraz udzielono odpowiedzi na następujące pytania:

- jaki jest poziom samooceny studentów kończących studia w odniesieniu do konkretnych umiejętności zawartych w T-shaped model (menedżerskich, interpersonalnych, analitycznych i stricte logistycznych);

- czy samoocena studentów - w zakresie wybranych umiejętności zawartych w T-shaped model - kończących studia na kierunku Logistyka jest znacząco (o min. 25\%) większa niż samoocena studentów rozpoczynających studia na tym kierunku (kończących I rok nauki).

\section{Kompetencje logistyczne jako potencjał konkurencyjności przedsiębiorstw}

Definicję logistyki można interpretować w trzech aspektach (Blaik, 2017):

1) koncepcyjno-funkcjonalnym - jako koncepcję zarządzania strategicznego, rozumianą jako określony kompleks przedsięwzięć i rozwiązań strukturalnych, odnoszących się do przepływów towarowych i informacyjnych;

2) przedmiotowo-strukturalnym - jako zintegrowany proces przepływów towarów i informacji oraz ich rejestrację w drodze od dostawców do konsumentów;

3) efektywnościowym - jako orientację w działaniu (przedsiębiorstwa), ukierunkowaną na oferowanie klientom pożądanego poziomu i jakości obsługi logistycznej (przy racjonalizacji struktury kosztów logistyki), a także wzrost efektywności gospodarowania środkami organizacji.

Ta wielopłaszczyznowość pozwala na postrzeganie logistyki nie tylko jako koncepcji zintegrowanego zarządzania całym przedsiębiorstwem lub siecią powiązań z partnerami rynkowymi (Blaik, 2017), lecz także jako narzędzia budowania potencjału konkurencyjności rynkowej podmiotu/sieci. Przyjmując, że potencjał konkurencyjności może być zdefiniowany jako system zasobów materialnych i niematerialnych, umożliwiających zastosowanie optymalnych instrumentów skutecznego konkurowania na rynkach (Stankiewicz, 1999), to jednym z zasobów mogą być kompetencje logistyczne przedsiębiorstwa. Autorzy ujednoliconej teorii logistyki - J. Mentzer, S. Min i L.M. Bobbit (2004) - wskazali m.in., że: 
- nasilenie konkurencji i niestabilność rynku powoduje, iż wzrasta znaczenie kompetencji logistycznych w osiąganiu celów partnerów w łańcuchu dostaw;

- kompetencje logistyczne pomagają przedsiębiorstwom pozyskiwać, analizować i rozpowszechniać informacje dotyczące oferty podmiotu i sposobu obsługi klienta wewnętrznego i zewnętrznego (wzdłuż całego łańcucha dostaw/powiązań sieciowych) w celu lepszej koordynacji i współpracy;

- zarządzanie wszystkimi zasobami w ramach łańcucha dostaw prowadzi do osiągania wyróżniających kompetencji logistycznych;

- kompetencje logistyczne, będące przewagą konkurencyjną, są wynikiem wspólnego zarządzania i realizacji celów partnerów w łańcuchu dostaw;

- logistyczne kompetencje w zarządzaniu popytem są wielowymiarowe (obsługa klienta i jakość logistyczna) oraz długofalowe (elementy przedtransakcyjne, transakcyjne i potransakcyjne obsługi klienta), przez co prowadzą do osiągania przewagi konkurencyjnej;

- logistyczne kompetencje w zarządzaniu podażą prowadzą do optymalizacji procesów biznesowych związanych z czynnościami logistycznymi, które prowadzą do obniżki kosztów, w konsekwencji zaś do przywództwa kosztowego (jako przewagi konkurencyjnej),

- kompetencje zarządzania przepływem informacji skupiają potrzeby informacyjne na poziomie operacyjnym i strategicznym w celu zrównoważenia podaży i popytu rynkowego oraz ułatwieniu dokonywania restrukturyzacji łańcucha dostaw (co powinno prowadzić do optymalizacji wydatków inwestycyjnych, w konsekwencji zaś do osiągnięcia kosztowej przewagi konkurencyjnej).

Przedstawione kompetencje logistyczne stwarzają możliwości, które dopiero w wyniku celowego zastosowania wpłyną na konkurencyjność przedsiębiorstwa/ /łańcucha dostaw/sieci przedsiębiorstw. Ich praktyczna realizacja - w ramach działań strategicznych, operacyjnych i taktycznych - pozostaje w gestii pracowników różnych szczebli. Zarządzający przedsiębiorstwami dostrzegają (powinni dostrzegać) te odmienne płaszczyzny i delegują do ich wykonywania osoby o odpowiednich kwalifikacjach. Jest to o tyle trudne wyzwanie, że różnorodność stanowisk logistycznych jest znaczna - wg Council of Logistics Management istnieje siedemnaście profesji logistycznych w przedsiębiorstwie ${ }^{4}$ (i nie jest to katalog zamknięty), które wymagają określonych umiejętności ${ }^{5}$.

4 Są to: logistyk analityk, logistyk doradca, menedżer magazynu, menedżer logistyki, logistyk-menedżer zapotrzebowania materiałowego, logistyk-menedżer produkcji, logistyk-menedżer zakupów, logistyk- menedżer zarządzania łańcuchami dostaw, logistyk-menedżer systemów podejmowania decyzji, logistyk-koordynator poziomu zapasów u sprzedawcy, logistyk-menedżer operacji magazynowych, menedżer logistyki usług, sprzedawca usług logistycznych, menedżer logistyki międzynarodowej, logistyk inżynier, logistyk informatyk, logistyk-menedżer transportu.

5 Więcej na ten temat - zob. Council of Logistic Management. 


\section{Umiejętności logistyków - ujęcie teoretyczne}

Potencjał konkurencyjności przedsiębiorstw jest również kreowany przez postawy i działania pracowników (zasób niematerialny podmiotu rynkowego), które można opisać jako kompetencje. Synteza definicji kompetencji ${ }^{6}$ przedstawionych przez prekursorów tego pojęcia - D. McClellanda (1973) czy R. Boyatzisa (1982) - pozwala na postrzeganie kompetencji jako wewnętrznej charakterystyki jednostki, która pozostaje w związku przyczynowo-skutkowym z opartymi na określonych kryteriach wyjątkowymi osiągnięciami w danej sytuacji (Spencer, Spencer, 1993). G. Hamel i C.K. Prahalad (1994) argumentują, iż z punktu widzenia efektywności w przyszłości dla organizacji szczególnie ważne jest skoncentrowanie się na rozwoju tych kompetencji, które prowadzą do wykształcenia nowych usług oraz wyróżniającej obsługi, nabierającej w podmiotach usługowych (np. branży TSL) szczególnego znaczenia.

Chociaż kompetencje są definiowane $\mathrm{w}$ różny sposób, można przyjąć, że (Kazibudzki, 2007):

- podstawą kompetencji są (Rakowska, 2007):

- wiedza, obejmująca m.in. najnowsze trendy i rozwiązania z zakresu organizacji i zarządzania, możliwości wykorzystania technologii informatycznej,

- umiejętności, na które składają się m.in. kierowanie sobą, planowanie i przewidywanie, zarządzanie zmianami, rozwiązywanie problemów i podejmowanie decyzji, umiejętność negocjacji i rozwiązywania konfliktów, budowanie dobrych relacji z innymi ludźmi i motywowanie pracowników,

- doświadczenie (tak zawodowe, jak i życiowe),

- postawa, na którą się składa: chęć i motywacja do uczenia się, otwartość na nowości i gotowość do podejmowania ryzyka, co najmniej przeciętna pewność siebie i energiczność, duża odporność na stres, otwartość na innych ludzi i głoszone przez nich idee, co najmniej przeciętna niezależność od innych oraz elastyczność w myśleniu (należy jednak mieć na uwadze fakt, że same cechy danej osoby nie przynoszą wartości dodanej, o ile nie zostaną wykorzystane do sprawnego i przynoszącego wymierne efekty działania);

6 G. Filipowicz (2004) zwrócił uwagę na fakt, że pojęcie „kompetencje” zawsze występuje w liczbie mnogiej - niezwykle trudno wyizolować pojedynczą kompetencję i traktować ją jako właściwość całkowicie oderwaną od innych kompetencji, niezależną, dlatego rozpatruje się wiązki, zbiory kompetencji w odniesieniu do określonych zawodów. 
- identyfikacja kompetencji zależy od przyjętej (istotnej z punktu widzenia specyfiki przedsiębiorstwa - branża, wielkość, forma własności, styl zarządzania itp.) koncepcji struktury obszarów kompetencji, na którą wpływa - szeroko rozumiane - otoczenie biznesu i w związku z tym oprócz kompetencji uniwersalnych występują kompetencje specjalistyczne (tu stricte logistyczne).

W artykule skoncentrowano się na umiejętnościach wybranej grupy pracowników - logistyków. Dlatego należy szczegółowo przedstawić specyfikę tej grupy zawodowej. Już dwadzieścia lat temu w literaturze (Gibson, Gibson, Rutner, 1998) wskazano cztery kategorie umiejętności wymaganych w zarządzaniu logistycznym:

1) umiejętności nakierowane na ludzi (m.in. praca w zespole, przywództwo, zarządzanie konfliktem),

2) umiejętności analityczne (m.in. diagnozowanie i rozwiązywanie problemów),

3) umiejętności komunikacyjne (m.in. komunikacja werbalna i niewerbalna, asertywność),

4) umiejętności związane $z$ obsługą komputera.

\section{Rysunek 1. Model T (umiejętności logistyków)}

\begin{tabular}{|c|c|c|}
\hline $\begin{array}{l}\quad \begin{array}{l}\text { Ogólne umiejętności } \\
\text { menedżerskie }\end{array} \\
\text { - } \quad \text { Finanse i rachunkowość } \\
\text { - } \text { IT } \\
\text { - } \\
\text { - Zarządzanie zmianą } \\
\text { - } \text { Marketing } \\
\text { - Zarządzanie projektami } \\
\text { - } \text { Zarządzanie strategiczne } \\
\text { - }\end{array}$ & $\begin{array}{l}\quad \text { Umiejętności } \\
\text { - } \\
\text { - Komterpersonalne } \\
\text { interpersonalna } \\
\text { - Słuchanie } \\
\text { - Komunikacja werbalna } \\
\text { - Komunikacja pisemna } \\
\text { - Prowadzenie spotkań } \\
\text { - Negocjacje } \\
\text { - Zarządzanie stresem } \\
\text { - HRM } \\
\text { - Przywództwo }\end{array}$ & $\begin{array}{l}\text { Umiejętności rozwiązywania } \\
\text { problemów } \\
\text { - Identyfikacja problemu, } \\
\text { - Gromadzenie informacji } \\
\text { - Analiza problemu } \\
\text { - Dzielenie się informacją } \\
\text { - Rozwiązywanie problemu }\end{array}$ \\
\hline & $\begin{array}{l}\text { Funkcjonalne umiejętności } \\
\text { logistyczne } \\
\text { - Prawo } \\
\text { - Cła, import/eksport } \\
\text { - Zarządzanie transportem } \\
\text { - Zarządzanie magazynem } \\
\text { - Składowanie } \\
\text { - Zakupy } \\
\text { - Planowanie. }\end{array}$ & \\
\hline
\end{tabular}

Źródło: opracowanie własne na podstawie Mangan, Christopher (2005). 
W kolejnych latach podejście to ewoluowało ${ }^{7}$ i zostało syntetycznie ujęte w „modelu T” (T-shaped model), który łączy ogólne umiejętności zarządzania, rozwiązywania problemów, jak również funkcjonalne umiejętności logistyczne (rysunek 1).

Kategorie umiejętności, zebrane w modelu T, zostały wykorzystane do budowy kwestionariusza ankiety, który posłużył do przeprowadzenia badania własnego.

\section{Umiejętności logistyków - ujęcie empiryczne}

Do badania - przeprowadzonego w maju 2017 r. - wykorzystano autorski kwestionariusz ankiety. Kwestionariusz, oprócz metryczki, zawierał pytania zamknięte, wymagające ustosunkowania się do podanych kwestii. Studenci, korzystając ze skali 1-6 (gdzie: 1 - całkowity brak umiejętności, zaś 6 - bardzo wysokie umiejętności), dokonywali samooceny w obszarach: umiejętności menedżerskie i interpersonalne oraz analityczne i funkcjonalne umiejętności logistyczne. Dobór grupy badawczej był celowy; objęto nim 176 studentów kierunku Logistyka (na Wydziale Ekonomiczno-Socjologicznym Uniwersytetu Łódzkiego). W dalszej części artykułu uwaga będzie skoncentrowana na wynikach pozyskanych od studentów II roku drugiego stopnia studiów (w konfrontacji z samooceną studentów I roku pierwszego stopnia studiów).

W badanej grupie respondentów (76 osób) kończących studia 72,4\% studiowało stacjonarnie, a 27,6\% - w trybie niestacjonarnym. Jeśli chodzi o strukturę płci, to przedstawiała się ona następująco: $48,7 \%$ to kobiety, a 51,3\% - mężczyźni. Na pytanie dotyczące planów po studiach $34,2 \%$ badanych odpowiedziało, że chciałoby podjąć pracę, 25\% - założyć własną firmę, a 6,6\% wskazań dotyczyło takich opcji, jak: pracować na zlecenie różnych podmiotów, mam inne plany, nie mam żadnych planów.

W stuosobowej grupie badanych studentów kończących I rok studiów licencjackich na kierunku Logistyka 45\% stanowiły kobiety (55\% mężczyźni); 63\% studiowało w trybie stacjonarnym (37\% - niestacjonarnym).

Przyjęto, że wyniki samooceny studentów kończących studia (II rok studiów drugiego stopnia) będą znacznie wyższe (min. o 25\%) niż studentów kończących I rok studiów pierwszego stopnia. Z uwagi na fakt, iż odpowiedzi miały rozkład normalny, wyniki są prezentowane za pomocą klasycznych miar statystycznych średniej arytmetycznej, dominanty, mediany.

\footnotetext{
7 Zmiany w tym zakresie - zob. Chmielecki (2012).
} 
W tabeli 1 przedstawiono wyniki badań dotyczące samooceny studentów w zakresie umiejętności menedżerskich. Wbrew oczekiwaniom, nie we wszystkie obszarach samoocena studentów kończących studia na kierunku Logistyka była wyższa niż respondentów kończących I rok studiów na tym kierunku - np. obszar dotyczący aspektów finansowych działania przedsiębiorstw (określony w ankiecie jako rozumienie istoty pojęcia „finanse”, umiejętność dokonywania analizy zjawisk zachodzących na rynku finansowym, umiejętność wyjaśnienia znaczenia wybranych instrumentów finansowych - np. stóp procentowych, podatków, kredytu). Trudno jednoznacznie interpretować tę sytuację - kategoria ta ma najniższą ocenę w badanej grupie, co wskazuje na deficyt w tym zakresie wśród studentów II roku studiów drugiego stopnia, jednakże relatywnie wysoka samoocena studentów I roku studiów pierwszego stopnia może wynikać z braku świadomości pełnego zakresu tego pojęcia.

Tabela 1. Wybrane umiejętności menedżerskie

\begin{tabular}{|l|r|r|r|c|c|}
\hline \multicolumn{1}{|c|}{ Umiejętność } & I r. & II r. & $\Delta \%$ & Do II r. & Me II r. \\
\hline Zarządzanie projektami & 3,07 & 3,76 & 22,5 & 3 & 4 \\
\hline Zarządzanie relacjami z klientami & 3,24 & 3,48 & 7,4 & 3 & 3 \\
\hline Zarządzanie zmianą & 3,09 & 3,35 & 8,4 & 3 & 3 \\
\hline Znajomość technologii informacyjnych & 4,01 & 4,75 & 18,5 & 5 & 5 \\
\hline Finanse & 3,43 & 3,14 & {$[-] 8,5$} & 3 & 3 \\
\hline Marketing & 3,74 & 4,21 & 12,6 & 4 & 4 \\
\hline Zarządzanie strategiczne & 2,92 & 3,79 & 29,8 & 3 & 4 \\
\hline Zarządzanie ryzykiem & 2,86 & 3,38 & 18,2 & 3 & 3 \\
\hline
\end{tabular}

Uwaga: I r. - średnia ocena studentów I roku pierwszego stopnia studiów; II r. - średnia ocena studentów II roku drugiego stopnia studiów; $\Delta \%$ - procentowa różnica między samooceną studentów II roku a I roku; Do II r. dominanta wskazań studentów II roku drugiego stopnia studiów; Me II r. - mediana wskazań studentów II roku drugiego stopnia studiów.

Źródło: opracowanie własne na podstawie wyników przeprowadzonego badania.

Respondenci najwyżej ocenili swoje umiejętności w zakresie znajomości technologii informacyjnych (dotyczy to obu grup studentów). Żaden ze studentów II roku studiów drugiego stopnia nie ocenił swoich umiejętności na poziomie ocen 1 i 2 , a dominanta i mediana wyniosły 5 . Jest to zrozumiałe $z$ uwagi na fakt, iż należą oni do „pokolenia Z” (pokolenia internetowego) (Pokolenie Z..., 2016), dorastającego $\mathrm{w}$ świecie nowoczesnych technologii, nastawionego na szybkie wyszukiwanie informacji i chętnego do dzielenia się informacjami w Sieci (co znajduje swoje potwierdzenie w ocenach zawartych w tabeli 2), pokolenia, dla którego 
najważniejsze jest budowanie relacji społecznych (co znajduje potwierdzenie w wybranych ocenach zawartych w tabeli 3). Tylko w jednej z ocenianych kategorii - zarządzanie strategiczne (określone w ankiecie jako proces informacyjno-decyzyjny, mający na celu rozstrzyganie o kluczowych decyzjach dotyczących funkcjonowania przedsiębiorstwa) - różnica w samoocenie studentów kończących studia była znacząco wyższa (o przeszło $25 \%$ ) niż studentów I roku.

Jeśli chodzi o umiejętności z zakresu rozwiązywania problemów - dostrzeganie problemu, opisanie, na czym polega i kogo dotyczy, wskazanie przyczyn i ewentualnych jego skutków, gromadzenie informacji, umiejętność dzielenia się wiedzą, potrafi wskazać alternatywne rozwiązania, potrafi wskazać zasoby konieczne do rozwiązania problemu - to we wszystkich kategoriach samoocena badanej grupy była wysoka - powyżej 4 (tabela 2). Znaczna różnica między studentami II roku drugiego stopnia studiów a badanymi rozpoczynającymi studia dotyczyła kategorii: gromadzenie informacji (żaden ze studentów II roku nie wystawił sobie ocen 1 i 2 w tym obszarze). Można przyjąć, że różnica ta wynika z odbytych przez respondentów studiów.

Tabela 2. Wybrane umiejętności z zakresu rozwiązywania problemów

\begin{tabular}{|l|c|c|c|c|c|}
\hline \multicolumn{1}{|c|}{ Umiejętność } & I r. & II r. & $\Delta \%$ & Do II r. & Me II r. \\
\hline Identyfikacja problemu & 4,13 & 4,49 & 8,7 & 4 & 4 \\
\hline Gromadzenie informacji & 3,19 & 4,51 & 41,4 & 4 & 4 \\
\hline Analiza problemu & 3,91 & 4,48 & 14,6 & 4 & 4 \\
\hline Dzielenie się informacją & 4,34 & 4,49 & 3,5 & 4 & 5 \\
\hline Rozwiązywanie problemów & 4,06 & 4,32 & 6,4 & 5 & 4 \\
\hline
\end{tabular}

Uwaga: I r. - średnia ocena studentów I roku pierwszego stopnia studiów; II r. - średnia ocena studentów II roku drugiego stopnia studiów; $\Delta \%$ - procentowa różnica między samooceną studentów II roku a I roku; Do II r. dominanta wskazań studentów II roku drugiego stopnia studiów; Me II r. - mediana wskazań studentów II roku drugiego stopnia studiów.

Źródło: opracowanie własne na podstawie wyników przeprowadzonego badania.

Z przywoływanego już zestawienia umiejętności logistyków różnych profesji (Council of Logistic Management) wynika, że umiejętności interpersonalne (na wysokim lub bardzo wysokim poziomie) są konieczne w przypadku pracowników, którzy mają wykonywać obowiązki w zakresie logistyki. Przyglądając się wynikom zawartym w tabeli 3, należy stwierdzić, że samoocena studentów kończących studia na kierunku Logistyka jest niezbyt wysoka. Jednak biorąc pod uwagę dostępne badania (UM-WUP, 2015), można wskazać, że chociaż przedstawiciele biznesu oczekują od absolwentów rozwiniętych kompetencji miękkich i biznesowych, nie podzielają oni opinii, iż to uczelnie w największym stopniu powinny być 
odpowiedzialne za ich uzyskanie przez studentów. Tym samym średnim poziomem umiejętności studentów w tym zakresie nie można obciążać jedynie uczelni ${ }^{8}$.

Tabela 3. Wybrane umiejętności interpersonalne

\begin{tabular}{|l|r|r|r|r|c|}
\hline \multicolumn{1}{|c|}{ Umiejętność } & I r. & II r. & $\Delta \%$ & Do II r. & Me II r. \\
\hline Komunikacja interpersonalna & 4,24 & 4,55 & 7,3 & 4 & 5 \\
\hline Negocjacje & 3,48 & 3,92 & 12,6 & 3 & 4 \\
\hline Przywództwo & 3,66 & 3,83 & 4,6 & 4 & 4 \\
\hline Współpraca w grupie & 4,60 & 4,83 & 5,0 & 5 & 5 \\
\hline Zarządzanie stresem & 3,29 & 3,72 & 13,1 & 3 & 4 \\
\hline Gotowość/chęć do pracy & 4,96 & 5,25 & 5,9 & 6 & 5 \\
\hline Chęć rozwijania własnych kompetencji & 4,78 & 5,04 & 5,4 & 6 & 5 \\
\hline $\begin{array}{l}\text { Chęć do nabywania nowych } \\
\text { umiejętności }\end{array}$ & 4,97 & 5,16 & 3,8 & 6 & 5 \\
\hline $\begin{array}{l}\text { Gotowość do uczestnictwa } \\
\text { w nieodpłatnych stażach/praktykach }\end{array}$ & 3,94 & 3,25 & {$[-] 17,5$} & 1 & 3 \\
\hline
\end{tabular}

Uwaga: I r. - średnia ocena studentów I roku pierwszego stopnia studiów; II r. - średnia ocena studentów II roku drugiego stopnia studiów; $\Delta \%$ - procentowa różnica między samooceną studentów II roku a I roku; Do II r. dominanta wskazań studentów II roku drugiego stopnia studiów; Me II r. - mediana wskazań studentów II roku drugiego stopnia studiów.

Źródło: opracowanie własne na podstawie wyników przeprowadzonego badania.

W tabeli 3 znalazła się również samoocena studentów w odniesieniu do zaangażowania - chęci do pracy, rozwijania własnych kompetencji i umiejętności - i choć studenci kończący studia ocenili się wyżej w tym obszarze (nikt nie wystawił sobie oceny 1) niż studenci I roku, to ta różnica jest niewielka. Na poziomie deklaracji studenci II roku ocenili wysoko swoje nastawienie do rozwoju (dominanta odpowiedzi 6, a mediana 5). Jednak biorąc pod uwagę realne zaangażowanie w trakcie studiów (zob. tabela 5), to sytuacja nie jest już tak optymistyczna - tylko około 1/3 respondentów brało udział w stażu w trakcie studiów i zajęciach z praktykami, a połowa $\mathrm{w}$ dodatkowych warsztatach/szkoleniach. Można zrozumieć mniejszą gotowość studentów II roku do uczestnictwa w nieodpłatnych stażach/ /praktykach niż studentów I roku - jako absolwenci studiów chcieliby już zarabiać na własne utrzymanie.

Ostatnią badaną kategorią były umiejętności stricte logistyczne (tabela 4). W tym zakresie średnia samoocena respondentów była najniższa (w żadnym

8 Warto w tym miejscu wskazać, że od roku akademickiego 2017/18 do programu studiów na kierunku Logistyka (na I roku) został wprowadzony nowy przedmiot - Komunikacja społeczna, który powinien się przyczynić do podniesienia poziomu umiejętności studentów w analizowanym obszarze. 
obszarze nie przekroczyła 4), choć dominanta i/lub mediana wynosiła 4. Tylko w jednym obszarze - logistycznych technologii informacyjnych średnia ocena studentów II roku była znacząco wyższa niż studentów I roku.

Tabela 4. Wybrane funkcjonalne umiejętności logistyczne

\begin{tabular}{|l|r|r|r|c|c|}
\hline \multicolumn{1}{|c|}{ Umiejętność } & I r. & II r. & $\Delta \%$ & Do II r. & Me II r. \\
\hline Prawo & 3,23 & 2,99 & {$[-] 7,4$} & 3 & 3 \\
\hline Cła, import/eksport & 2,89 & 3,38 & 17,0 & 3 & 3 \\
\hline Zarządzanie transportem & 3,45 & 3,79 & 9,9 & 4 & 4 \\
\hline Zarządzanie magazynem & 3,57 & 3,17 & {$[-] 11,2$} & 3,4 & 4 \\
\hline Składowanie & 3,46 & 3,75 & 8,4 & 4 & 4 \\
\hline Organizacja zakupów & 3,64 & 3,95 & 8,5 & 4 & 4 \\
\hline Planowanie procesów logistycznych & 3,53 & 3,95 & 11,9 & 3 & 4 \\
\hline Logistyczne technologie informacyjne & 2,93 & 3,73 & 27,3 & 4 & 4 \\
\hline
\end{tabular}

Uwaga: I r. - średnia ocena studentów I roku pierwszego stopnia studiów; II r. - średnia ocena studentów II roku drugiego stopnia studiów; $\Delta \%$ - procentowa różnica między samooceną studentów II roku a I roku; Do II r. dominanta wskazań studentów II roku drugiego stopnia studiów; Me II r. - mediana wskazań studentów II roku drugiego stopnia studiów.

Źródło: opracowanie własne na podstawie wyników przeprowadzonego badania.

Z badań wynika (UM-WUP, 2015), że jeśli chodzi o kompetencje specjalistyczne (wiedza i umiejętności), to - zdaniem przedstawicieli biznesu - powinny za nie odpowiadać szkoły wyższe. Tym samym wyniki badania mogą stanowić impuls do zmian w kształceniu studentów na badanej uczelni.

Tabela 5. Aktywność studentów II roku studiów drugiego stopnia w trakcie nauki (w \%)

\begin{tabular}{|l|c|c|}
\hline \multicolumn{1}{|c|}{ Respondent uczestniczył } & Tak & Nie \\
\hline W płatnym stażu & 35,5 & 64,5 \\
\hline W bezpłatnym stażu & 30,3 & 69,7 \\
\hline W warsztatach/szkoleniach & 55,3 & 44,7 \\
\hline Zajęciach z praktykami & 39,5 & 60,5 \\
\hline W badaniach prowadzonych przez instytucje/przedsiębiorstwa & 14,5 & 85,5 \\
\hline
\end{tabular}

Źródło: opracowanie własne na podstawie wyników przeprowadzonego badania.

Na kompetencje pracowników czy kandydatów do pracy - oprócz wiedzy i osobowości - składa się również profil osobowościowy. Jak już zostało powiedziane, w badaniu znalazło się także odniesienie do aktywności studentów w trakcie 
studiów, co pozwoliło na pokazanie proaktywnych postaw respondentów na średnim poziomie (tabela 5 ).

\section{Podsumowanie}

Zdobywanie przez przedsiębiorstwa kluczowych kompetencji logistycznych staje się krokiem w kierunku poprawy konkurencyjności podmiotu. Nie będzie ono możliwe bez pracowników o odpowiednich kwalifikacjach. Rosnące znaczenie logistyki (tak w ujęciu makroekonomicznym - branża TSL, jak i mikro - narzędzie poprawy efektywności i integracji przepływów w przedsiębiorstwie czy mezo - filozofia współpracy podmiotów w ramach zintegrowanych łańcuchów/sieci dostaw), sprawia, że od pracowników zatrudnionych „w logistyce” oczekuje się realizowania zróżnicowanych zadań i funkcji, a tym samym od obecnych i potencjalnych pracowników wymaga się często interdyscyplinarnej wiedzy i wielorakich umiejętności. Rozpoznanie umiejętności niezbędnych „w logistyce” jest ważne nie tylko dla pracodawców, lecz także dla potencjalnych pracowników, a w konsekwencji - dla uczelni w celu konstruowania/modyfikacji programów edukacji.

W artykule zaprezentowano wyniki - w obszarze umiejętności menedżerskich, interpersonalnych, analitycznych i stricte logistycznych - uzyskane od studentów II roku studiów drugiego stopnia (w konfrontacji z wynikami studentów I roku studiów pierwszego stopnia). Najwyższa samoocena (średnia wskazań powyżej 5) dotyczyła: gotowości do pracy, chęci rozwijania kompetencji i nabywania nowych umiejętności. Nieco niższa ocena (średnia wskazań powyżej 4) dotyczyła umiejętności z zakresu rozwiązywania problemów, następnie umiejętności interpersonalnych (najwyżej ocenione: komunikacja interpersonalna i umiejętność pracy w grupie) i umiejętności menedżerskich (najwyżej ocenione umiejętności z zakresu technologii informacyjnych i marketingu).

Wbrew oczekiwaniom, w niewielu obszarach samoocena studentów II roku studiów drugiego stopnia była zdecydowanie wyższa niż studentów rozpoczynających edukację (dotyczyło to tylko wiedzy z zakresu zarządzania strategicznego i gromadzenia informacji), a w niektórych była nawet niższa (finanse, prawo, zarządzanie magazynem). Najniższa samoocena badanych dotyczyła funkcjonalnych umiejętności logistycznych, dlatego konieczne są zmiany w kształceniu studentów, by postrzeganie własnej wiedzy i umiejętności z zakresu logistyki było na wyższym poziomie. Drugi wniosek dotyczy tego, że badania będą kontynuowane w najbliższych latach tak, aby objąć nimi studenta „na wejściu” do systemu kształcenia akademickiego oraz na „wyjściu”, aby możliwa była ewaluacja samooceny umiejętności tej samej grupy osób. 


\section{Bibliografia}

Blaik, P. (2017). Logistyka. Koncepcja zintegrowanego zarzq̨dzania. Warszawa: PWE.

Boyatzis, R. (1982). The Competent Manager. A Model for Effective Performance. New York: John Wiley \& Sons Inc.

Chmielecki, M. (2012). Umiejętności i kompetencje kadry zarządzającej w logistyce.

Przedsiębiorczość i Zarządzanie. Zarządzanie Logistyczne, XIII(16), 21-31.

Council of Logistic Management. Careers in Logistics. www.academic.rcc.edu/logisticsmanagement (12.11.2017).

Filipowicz, G. (2004). Zarzadzanie kompetencjami zawodowymi. Warszawa: PWE.

Gibson, B., Gibson, M., Rutner, S. (1998). Careers in Logistics. Oak Brook, IL: Council of Logistics Management.

Hamel, G., Prahalad, C.K. (1994). Competing for the Future. Harvard Business Review, July-August, 69-82.

Kazibudzki, P. (2007). Kompetencje przedsiębiorcy-menedżera. Ideologia kształtowania. Szczecin: Wydawnictwo My Book.

Łupicka, A. (2005). Teorie wyjaśniające powstawanie i funkcjonowanie sieci logistycznych. LogForum, 1(1), 1-12.

Mangan, J., Christopher, M. (2005). Management development and the supply chain management of the future. International Journal of Logistics Management, 16(2), 178-191.

McClelland, D. (1973). (1973). Testing for competence rather than for "intelligence". American Psychologist, 28, 1-14.

Mentzer, J., Min, S., Bobbit, L.M. (2004). Toward a Unifield Theory of Logistics. International Journal of Physical. Distribution and Logistics Management, 8, 606-627.

Pokolenie Z na rynku pracy - charakterystyka (2016). www.poradnikprzedsiebiorcy.pl (21.11.2017).

Rakowska, A. (2007). Kompetencje kadry kierowniczej we współczesnych organizacjach. Lublin: Wydawnictwo Uniwersytetu Marii Curie-Skłodowskiej.

Simmonds, K. (1986). The Accounting Assessment of Competitive Position. European Journal of Marketing, 20(1), 16-31.

Spencer, L.M., Spencer, S.M. (1993). Competence at work: Models for superior performance. New York: John Wiley \& Sons Inc.

Stankiewicz, M.J. (red.) (1999). Budowanie potencjału konkurencyjności przedsiębiorstwa. Torun: TNOiK „Dom Organizatora”.

Stankiewicz, M.J. (2005). Konkurencyjność przedsiębiorstwa. Budowanie konkurencyjności przedsiębiorstwa w warunkach globalizacji. Toruń: TNOiK „Dom Organizatora”.

UM-WUP (2015). Bilans kompetencji w branży transport i logistyka. Raport z przeprowadzonych badań. Kraków. 


\section{Summary}

\section{Skills of Logistics Students According to T-Shaped Model (Based on Research)}

Enterprises, striving for a market success, are forced to cooperate with other market participants (both suppliers and customers). Therefore, management of a modern company requires taking into consideration an issue of competitiveness within the entire logistics chain (and not just the competitiveness of a given entity). The paper represents a theoretical and empirical approach. The theoretical part refers to logistics competitiveness potential - indicates logistics competencies of enterprises and logistics skills of employees according to the T model, and in the empirical part - presents the results of own research regarding a self-assessment of students' skills II, belonging to second degree of logistics, according to the $\mathrm{T}$ model.

Keywords: logistics competence, logistics skills (management, interpersonal, ability to solving problem, functional skills), logistics students, own research

\section{Dr hab. Agnieszka Bukowska-Piestrzyńska, prof. UŁ}

Kierownik Katedry Logistyki oraz zastępca Dyrektora Instytutu Ekonomik Stosowanych i Informatyki na Wydziale Ekonomiczno-Socjologicznym Uniwersytetu Łódzkiego. Od kilkunastu lat zajmuje się problematyką funkcjonowania przedsiębiorstw usługowych w obszarze zarządzania, marketingu i logistyki (ze szczególnym uwzględnieniem obsługi klienta). Autorka kilkadziesięciu artykułów i siedmiu książek z tego zakresu. 